\title{
Steric hindrance effects in tripodal ligands for extraction and back-extraction of $\mathrm{Ag}^{+} \dagger$
}

Cite this: RSC Adv., 2014, 4, 9791

\author{
Yuki Hiruta, $\$ \S^{a}{ }^{2}$ Takafumi Watanabe, $\S^{a}$ Etsuko Nakamura, ${ }^{a}$ Naoko Iwasawa, ${ }^{a}$ \\ Hiroyasu Sato, ${ }^{b}$ Kensaku Hamada, ${ }^{\text {b }}$ Daniel Citterio ${ }^{a}$ and Koji Suzuki ${ }^{\star a}$
}

A novel series of tripodal ligands with thiophenylether arms connected to an anchoring nitrogen has been investigated. Seven tripodal ligands were synthesized by combining methyl, isopropyl, and tert-butyl residue bearing thiophenylether sites as groups with different steric hindrance effects. The tripodal ligands allowed for the extraction of $\mathrm{Ag}^{+}$ions from the aqueous phase into a chloroform phase by forming $1: 1$ complexes with $\mathrm{Ag}^{+}$. Back-extraction was performed with $1 \mathrm{M} \mathrm{HNO}_{3}$ aqueous solution. Each ligand showed different extraction and back-extraction efficiency for $\mathrm{Ag}^{+}$, affected by changes in steric hindrance caused by the various combinations of sidearms. These results are further supported by $\mathrm{X}$-ray single crystal structural analysis.

Received 10th October 2013

Accepted 27th January 2014

DOI: 10.1039/c3ra45700a

www.rsc.org/advances

On the other hand, studies focusing on the relationship

\section{Introduction}

Coordination chemistry is relevant for complex formation and molecular recognition. In this context, tripodal ligands having multidentate structure have attracted special interest. A tripodal ligand is characterized by its molecular structure with three coordinating arms. Typically, each of the coordinating arms having one or more donor atoms $(\mathrm{N}, \mathrm{O}, \mathrm{S}, \mathrm{P})$ is connected to an anchoring nitrogen or phosphorous atom. ${ }^{1}$ As coordinating arms, pyridyl, ${ }^{2}$ quinolyl, ${ }^{3}$ alkoxyl, ${ }^{4}$ and thioether ${ }^{5}$ groups have been presented, among others. In particular, tripodal ligands have been used as extractants for metals..$^{6-10}$

From an economic and environmental standpoint, it is of great importance to recover expensive metals for reuse and recycling from electronic waste, or to remove metal contaminants from wastewater. ${ }^{11-15}$ Examples include heavy metals, radioactive precious metals, rare metals, and rare earth metals. Solvent extraction is a very useful method to separate and concentrate metal cations in solution, and is widely applied for separations on industrial scale, such as in hydrometallurgy. There are many reports on the extraction of metal cations using various kinds of extractants, including studies focusing on the relationship between extraction efficiency and ligand structure. ${ }^{16-18}$

\footnotetext{
${ }^{a}$ Department of Applied Chemistry, Faculty of Science and Technology, Keio University, 3-14-1 Hiyoshi, Kohoku-ku, Yokohama 223-8522, Japan. E-mail: suzuki@applc.keio. ac.jp; Fax: +81 45566 1566; Tel: +81455661566

${ }^{\circ}$ Rigaku Corporation, 3-9-12, Matsubara-cho, Akishima-shi, Tokyo, 196-8666, Japan $\dagger$ Electronic supplementary information (ESI) available: NMR-spectra, HRMS spectra, ESI-MS spectra. CCDC 936706 and 936707. For ESI and crystallographic data in CIF or other electronic format see DOI: $10.1039 / \mathrm{c} 3 \mathrm{ra} 45700 \mathrm{a}$

\$ Present address: Division of Physical Pharmaceutical Chemistry, Faculty of Pharmacy, Keio University, 1-5-30 Shibakoen, Minato-ku, Tokyo 105-8512, Japan. $\S$ These authors have equally contributed to this work.
} between back-extraction efficiency and ligand structure are hardly found, so far. In the back-extraction process, the target component is transferred back to the aqueous phase by extraction of the organic phase with an aqueous solution under conditions shifting the distribution equilibrium of the target component away from the organic phase. That distribution equilibrium is controlled by the reagent concentrations, and the $\mathrm{pH}$ of the aqueous phase. In a metal recycling process, the backextraction represents a second extraction step, and allows for further selectivity improvement by choosing a suitable aqueous phase composition. For example, Narita et al. successfully recovered Rh prior to Pd and Pt by effective control of backextraction conditions. ${ }^{19}$

According to the HSAB concept, ${ }^{20}$ 'soft' acids such as transition metal ions, and sulfur atoms characterized as 'soft' bases generally have a strong affinity for each other. Therefore, there are a variety of sulfur containing structures reported as ligands for soft metal ions, in the form of macrocycles, ${ }^{21}$ crown ethers, ${ }^{22}$ lariat ethers, ${ }^{23}$ cryptands, ${ }^{24}$ calixarenes,${ }^{25}$ and tripodal ligands. ${ }^{26}$ However, with a strong coordination bond formed between the soft sulfur donor site and a soft transition metal ion like $\mathrm{Ag}^{+}$, the use of an aqueous mineral acid is no longer sufficient for the efficient release of the metal cation for back-extraction. In that case, compounds with stronger interaction with $\mathrm{Ag}^{+}$, such as ammonia or thiourea, are required in the aqueous phase. ${ }^{27}$

In the present work, the influence of steric hindrance in a tripodal ligand on the back-extraction efficiency with an aqueous mineral acid was investigated. For this purpose, a new series of tripodal ligands $(\mathbf{6 a}-\mathbf{g})$ with three thiophenylether sidearms connected to an anchoring nitrogen has been synthesized and characterized. The effect of steric hindrance induced by combinations of methyl, isopropyl, and tert-butyl 
substituted thiophenylether sidearms on extraction and backextraction efficiencies of $\mathrm{Ag}^{+}$was evaluated. In addition, X-ray crystal structure analyses of the tripodal ligands with $\mathrm{Ag}^{+}$have been performed for studying the binding structure.

\section{Experimental}

\section{Reagents and instruments}

All reagents for the syntheses of tripodal ligands $(\mathbf{6 a}-\mathbf{g})$ were purchased from the following commercial suppliers and were used without further purification: Wako Pure Chemical (Osaka, Japan), Tokyo Kasei Industry (Tokyo, Japan) and Aldrich Chemical (St. Louis, MO, U.S.A.). ${ }^{1} \mathrm{H}-\mathrm{NMR}$ and ${ }^{13} \mathrm{C}-\mathrm{NMR}$ spectra were recorded at room temperature on a JEOL ECA-500 spectrometer at $500 \mathrm{MHz}$ and $125 \mathrm{MHz}$, respectively. All chemical shifts are relative to an internal standard of tetramethylsilane $(\delta=0.0 \mathrm{ppm})$, and coupling constants are given in Hz. Highresolution mass spectra were obtained on a Waters Xevo G2-S QTof MS. ESI-mass spectra were obtained on a LCMS-2010EV (SHIMADZU, Kyoto, Japan). Flash chromatography separation was undertaken using a YFLC-Al-560 chromatograph (Yamazen Co., Osaka, Japan). ICPS-8000 inductively coupled argon plasma atomic emission spectrometry (SHIMADZU, Kyoto, Japan) was used for the determination of the concentration of each metal ion in aqueous solution. The deionized water used had a resistivity of $18.2 \mathrm{M} \Omega$ at $25^{\circ} \mathrm{C}$. The pH values were verified using an IOL-50 ion-meter (DKK-TOA Corp., Tokyo, Japan) with a glass $\mathrm{pH}$ electrode. All X-ray crystal structure measurements were performed with a Rigaku Saturn70 diffractometer using multilayer mirror monochromated Mo-K $\alpha(\lambda=0.71075 \AA)$ radiation. The structure was solved by direct methods, and expanded using Fourier techniques. Non-hydrogen atoms were refined anisotropically. Structural refinements were obtained with fullmatrix least-squares based on $F^{2}$ using the program SHELXL-97. ${ }^{28}$

\section{Synthesis}

2-Thio-substituted benzoic acid (2a and $2 \mathbf{b}$ ) was prepared as previously reported. ${ }^{29}$

2-(tert-Butylthio)benzoic acid (2c). 1 (4.92 g, $31.9 \mathrm{mmol}$ ) was dissolved in a mixture of acetic acid $(46 \mathrm{~mL}), 60 \%$ perchloric acid $(10 \mathrm{~mL})$, acetic anhydride $(8 \mathrm{~mL})$ and THF $(40 \mathrm{~mL})$. Then, tertiary butyl alcohol $(4.68 \mathrm{~g}, 63.1 \mathrm{mmol})$ was added and the solution was stirred for $18 \mathrm{~h}$ at room temperature, followed by $2 \mathrm{~h}$ at $50{ }^{\circ} \mathrm{C}$. After the reaction was completed, the reaction mixture was allowed to cool to room temperature, and excess saturated aqueous $\mathrm{NaHCO}_{3}$ solution was added to hydrolyze remaining acetic anhydride. After that, the $\mathrm{pH}$ of the solution was lowered to $\mathrm{pH} 1$ by addition of $1 \mathrm{M} \mathrm{HCl} \mathrm{solution.} \mathrm{The} \mathrm{acidic}$ aqueous phase was extracted with ethyl acetate 3 times, and the combined organic layer was washed with water two times and brine once, dried over $\mathrm{Na}_{2} \mathrm{SO}_{4}$, and the solvent evaporated. The resulting residue was used for the following reaction without further purification.

General procedure for the synthesis of 2-thio-substituted phenylmethanol compounds (3a-c). The corresponding 2-thio-substituted benzoic acid 2a-c was dissolved in THF $(200 \mathrm{~mL})$ and then cooled in an ice-bath $\left(0^{\circ} \mathrm{C}\right) .1 \mathrm{M} \mathrm{BH}_{3} \cdot \mathrm{THF}(70$ $\mathrm{mL}$ ) was added to the flask, and the reaction was stirred at $0{ }^{\circ} \mathrm{C}$ for $1 \mathrm{~h}$ and then at room temperature for $3 \mathrm{~h}$. It was then cooled in an ice bath and quenched by the careful addition of water. Solid $\mathrm{K}_{2} \mathrm{CO}_{3}$ was added until the solution was saturated, and the layers were separated. The organic layer was evaporated to dryness, while the aqueous phase was extracted with diethylether 2 times. All of the organic phases were combined, washed with $1 \mathrm{M} \mathrm{NaOH}$, water, and brine, dried over $\mathrm{Na}_{2} \mathrm{SO}_{4}$, evaporated, and dried under vacuum.

(2-(Methylthio)phenyl)methanol (3a). Compound 2a (14.1 g, $83.7 \mathrm{mmol}$ ) was used as the starting material, and 3a was obtained as clear oily liquid $(12.2 \mathrm{~g}, 94.3 \%) .{ }^{1} \mathrm{H}-\mathrm{NMR}\left(\mathrm{CDCl}_{3}\right.$, $500 \mathrm{MHz}) \delta(\mathrm{ppm}): 2.49(\mathrm{~s}, 3 \mathrm{H}), 4.75(\mathrm{~s}, 2 \mathrm{H}), 7.18-7.20(\mathrm{~m}, 1 \mathrm{H})$, 7.26-7.29 (m, 2H), $7.37(\mathrm{~d}, J=7.4 \mathrm{~Hz}, 1 \mathrm{H}) .{ }^{13} \mathrm{C}-\mathrm{NMR}\left(\mathrm{CDCl}_{3}, 125\right.$ MHz) $\delta$ (ppm): 16.21, 63.59, 125.61, 126.68, 128.11, 128.49, 136.76, 138.98.

(2-(Isopropylthio)phenyl)methanol (3b). Compound $2 \mathbf{b}$ (4.98 g, $25.4 \mathrm{mmol}$ ) was used as the starting material, and $\mathbf{3 b}$ was obtained as light yellow oily liquid ( $4.54 \mathrm{~g}, 98.2 \%) .{ }^{1} \mathrm{H}-\mathrm{NMR}$ $\left(\mathrm{CDCl}_{3}, 500 \mathrm{MHz}\right) \delta(\mathrm{ppm}): 1.30(\mathrm{~d}, J=6.9 \mathrm{~Hz}, 6 \mathrm{H}), 2.47(\mathrm{br}, 1 \mathrm{H})$, 3.38 (sep, $J=6.9 \mathrm{~Hz}, 1 \mathrm{H}), 4.79(\mathrm{~s}, 2 \mathrm{H}), 7.24-7.25$ (m, 2H), 7.39$7.45(\mathrm{~m}, 2 \mathrm{H}) .{ }^{13} \mathrm{C}-\mathrm{NMR}\left(\mathrm{CDCl}_{3}, 125 \mathrm{MHz}\right) \delta(\mathrm{ppm}): 23.30,38.97$, $64.11,127.48,128.21,128.57,133.04,133.94,142.40$.

(2-(tert-Butylthio)phenyl)methanol (3c). Compound 2c was used as the starting material, and $3 \mathbf{c}$ was obtained as light yellow oily liquid $(5.81 \mathrm{~g}, 93.0 \%) .{ }^{1} \mathrm{H}-\mathrm{NMR}\left(\mathrm{CDCl}_{3}, 500 \mathrm{MHz}\right) \delta$ (ppm): 1.31 (s, 9H), 2.52 (br, 1H), 4.87 (s, 2H), 7.25-7.28 (m, 1H), $7.35-7.38(\mathrm{~m}, 1 \mathrm{H}), 7.47(\mathrm{~d}, J=7.5 \mathrm{~Hz}, 1 \mathrm{H}), 7.54(\mathrm{~d}, J=7.8 \mathrm{~Hz}$, 1H). ${ }^{13} \mathrm{C}-\mathrm{NMR}\left(\mathrm{CDCl}_{3}, 125 \mathrm{MHz}\right) \delta(\mathrm{ppm}): 31.30,47.76,64.67$, 127.70, 128.75, 129.45, 131.15, 138.96, 145.94 .

Alkyl-substituted (2-(bromomethyl)phenyl)sulfates (4a and 4b) were prepared as previously reported. ${ }^{29}$

(2-(Bromomethyl)phenyl)(tert-butyl)sulfate (4c). Compound 3 c $(5.81 \mathrm{~g}, 29.6 \mathrm{mmol})$ was dissolved in diethylether $(300 \mathrm{~mL})$. After cooling to $0{ }^{\circ} \mathrm{C}, \mathrm{PBr}_{3}(4.00 \mathrm{~g}, 14.8 \mathrm{mmol})$ was added and the reaction was stirred at $0{ }^{\circ} \mathrm{C}$ for $0.5 \mathrm{~h}$ and room temperature for $1 \mathrm{~h}$. After the reaction was completed, the reaction was quenched with methanol. Then, water was added, and the organic layer was washed with saturated $\mathrm{NaHCO}_{3}$ three times and dried over $\mathrm{Na}_{2} \mathrm{SO}_{4}$, evaporated and dried under vacuum. 4c was obtained as colorless oily liquid $(6.70 \mathrm{~g}$, $87.4 \%)$.

${ }^{1} \mathrm{H}-\mathrm{NMR}\left(\mathrm{CDCl}_{3}, 500 \mathrm{MHz}\right) \delta(\mathrm{ppm}): 1.32(\mathrm{~s}, 9 \mathrm{H}), 4.88(\mathrm{~s}, 2 \mathrm{H})$, 7.24-7.27 (m, 1H), 7.33-7.36 (m, 1H), 7.56 (d, $J=7.7 \mathrm{~Hz}, 2 \mathrm{H})$. ${ }^{13} \mathrm{C}-\mathrm{NMR}\left(\mathrm{CDCl}_{3}, 125 \mathrm{MHz}\right) \delta(\mathrm{ppm}): 31.38,32.80,47.47,128.47$, 129.60, 131.13, 132.62, 139.02, 142.96.

General procedure for the synthesis of 2-thio-substituted phenylmethanamines (5a-c). The corresponding alkylsubstituted (2-(bromomethyl)phenyl)sulfate $\mathbf{4 a - c}$ was dissolved in ethanol $(160 \mathrm{~mL})$. Then, $28-30 \mathrm{wt} \%$ aqueous ammonia solution $(80 \mathrm{~mL})$ and THF $(80 \mathrm{~mL})$ were added, and the reaction was stirred at room temperature overnight. After the reaction was completed, the solvent was evaporated and the residue was dried under vacuum, before being purified by flash chromatography (silica gel). 
(2-(Methylthio)phenyl)methanamine (5a). Compound 4a (3.61 g, $16.6 \mathrm{mmol}$ ) was used as the starting material, and $\mathbf{5 a}$ was obtained as a white powder $(2.20 \mathrm{~g}, 86.4 \%)$. Eluent for chromatography: chloroform-methanol 94:6 $\rightarrow$ 90:10 $\rightarrow$ 85 : 15. ${ }^{1} \mathrm{H}-\mathrm{NMR}\left(\mathrm{CD}_{3} \mathrm{OD}, 500 \mathrm{MHz}\right) \delta(\mathrm{ppm}): 2.54(\mathrm{~s}, 3 \mathrm{H}), 4.24$ (s, 2H), 7.26-7.28 (m, 1H), 7.41-7.47 (m, 3H). ${ }^{13} \mathrm{C}-\mathrm{NMR}\left(\mathrm{CD}_{3} \mathrm{OD}\right.$, $125 \mathrm{MHz}) \delta$ (ppm): 16.53, 41.98, 127.17, 128.97, 130.83, 131.19, 132.74, 139.62 .

(2-(Isopropylthio)phenyl)methanamine (5b). Compound $4 \mathbf{b}$ $(4.51 \mathrm{~g}, 18.4 \mathrm{mmol})$ was used as the starting material, and $\mathbf{5 b}$ was obtained as a white powder (2.68 g, 80.4\%). Eluent for chromatography: chloroform-methanol 100:0 $\rightarrow$ 98:2 $\rightarrow$ $50: 50 .{ }^{1} \mathrm{H}-\mathrm{NMR}\left(\mathrm{CD}_{3} \mathrm{OD}, 500 \mathrm{MHz}\right) \delta(\mathrm{ppm}): 1.29(\mathrm{~d}, J=6.9 \mathrm{~Hz}$, $6 \mathrm{H}), 3.41$ (sep, $J=6.9 \mathrm{~Hz}, 1 \mathrm{H}), 4.34(\mathrm{~s}, 2 \mathrm{H}), 7.37-7.44(\mathrm{~m}, 2 \mathrm{H})$, 7.52 (d, $J=7.5 \mathrm{~Hz}, 1 \mathrm{H}), 7.61$ (dd, $J=7.5 \mathrm{~Hz}, 1.2 \mathrm{~Hz}, 1 \mathrm{H}) .{ }^{13} \mathrm{C}-$ NMR (125 MHz, $\left.\mathrm{CD}_{3} \mathrm{OD}\right) \delta$ (ppm): 23.36, 40.58, 42.56, 129.23, 130.91, 131.03, 135.25, 136.27, 136.68 .

(2-(tert-Butylthio)phenyl)methanamine (5c). Compound $4 \mathrm{c}$ $(2.31 \mathrm{~g}, 8.92 \mathrm{mmol})$ was used as the starting material, and $\mathbf{5 c}$ was obtained as a white powder $(1.30 \mathrm{~g}, 69.3 \%)$. Eluent for chromatography: chloroform-methanol $90: 10 .{ }^{1} \mathrm{H}-\mathrm{NMR}$ $\left(\mathrm{CD}_{3} \mathrm{OD}, 500 \mathrm{MHz}\right) \delta(\mathrm{ppm}): 1.30(\mathrm{~s}, 9 \mathrm{H}), 4.47$ (s, 2H), 7.44-7.47 (m, 1H), 7.50-7.53 (m, 1H), $7.62(\mathrm{~d}, J=7.8 \mathrm{~Hz}, 1 \mathrm{H}), 7.69(\mathrm{~d}, J=$ $7.8 \mathrm{~Hz}, 1 \mathrm{H}) .{ }^{13} \mathrm{C}-\mathrm{NMR}\left(\mathrm{CD}_{3} \mathrm{OD}, 125 \mathrm{MHz}\right) \delta(\mathrm{ppm}): 30.29,42.19$, $129.54,130.22,130.25,133.19,138.58,139.69$.

General procedure for the synthesis of alkyl-substituted $\mathrm{N}, \mathrm{N}$ bis(2-thiobenzyl)-1-(2-thiophenyl)-methanamines (6a-g). The corresponding alkyl-substituted (2-(bromomethyl)phenyl) sulfate (4a-c), 2-thio-substituted phenylmethanamine (5a-c) and $\mathrm{K}_{2} \mathrm{CO}_{3}$ were dissolved in acetonitrile and then stirred at room temperature for 1 day. After the reaction was completed, solids were removed by filtration, and the solvent was removed by evaporation. The resulting residue was purified by flash chromatography (silica gel).

Tris(2-(methylthio)benzyl)amine (6a). Compound $\quad 4 a$ (1443 mg, $6.64 \mathrm{mmol}$ ), compound 5a (506 mg, $3.30 \mathrm{mmol}$ ) and $\mathrm{K}_{2} \mathrm{CO}_{3}(2.00 \mathrm{~g}, 14.5 \mathrm{mmol})$ in acetonitrile $(200 \mathrm{~mL})$ were used. $6 \mathrm{a}$ was obtained as a white powder (1024 mg, 72.4\%). Eluent for chromatography: chloroform-methanol 100:0 $\rightarrow$ 99:1 $\rightarrow$ 90 : 10. ${ }^{1} \mathrm{H}-\mathrm{NMR}\left(\mathrm{CDCl}_{3}, 500 \mathrm{MHz}\right) \delta(\mathrm{ppm}): 2.40(\mathrm{~s}, 9 \mathrm{H}), 3.74(\mathrm{~s}$, $6 \mathrm{H}), 7.13-7.25(\mathrm{~m}, 9 \mathrm{H}), 7.69$ (d, $J=7.5 \mathrm{~Hz}, 3 \mathrm{H}) .{ }^{13} \mathrm{C}-\mathrm{NMR}$ $\left(\mathrm{CDCl}_{3}, 125 \mathrm{MHz}\right) \delta(\mathrm{ppm}): 16.13,55.79,125.05,125.54,127.31$, 128.84, 137.55, 137.67. HRMS: calculated for $\mathrm{C}_{24} \mathrm{H}_{27} \mathrm{NS}_{3}$ 426.1384 $[\mathrm{M}+\mathrm{H}]^{+}$; found 426.1387. Elemental analysis: calcd $\mathrm{C}$ $67.72, \mathrm{H} 6.39$, N 3.29, S 22.60; found C 67.73, H 6.55, N 3.22, S 22.61 .

$N$-(2-(Isopropylthio)benzyl)- $N$-(2-(methylthio)benzyl)-1-(2-(methylthio)phenyl)methanamine (6b). Compound $4 a$ (1180 mg, 5.43 $\mathrm{mmol}$ ), compound $\mathbf{5 b}(504 \mathrm{mg}, 2.78 \mathrm{mmol})$ and $\mathrm{K}_{2} \mathrm{CO}_{3}(2.00 \mathrm{~g}$, $14.5 \mathrm{mmol}$ ) in acetonitrile $(250 \mathrm{~mL})$ were used. $6 \mathbf{b}$ was obtained as lightly yellow solid (773 mg, 61.2\%). Eluent for chromatography: hexane-ethyl acetate $88: 12 \rightarrow 80: 20 \rightarrow 50: 50$. ${ }^{1} \mathrm{H}-\mathrm{NMR}\left(\mathrm{CDCl}_{3}, 500 \mathrm{MHz}\right) \delta(\mathrm{ppm}): 1.25(\mathrm{~d}, J=6.6 \mathrm{~Hz}, 6 \mathrm{H}), 2.41$ $(\mathrm{s}, 6 \mathrm{H}), 3.29$ (sep, $J=6.6 \mathrm{~Hz}, 1 \mathrm{H}), 3.73(\mathrm{~s}, 4 \mathrm{H}), 3.84(\mathrm{~s}, 2 \mathrm{H}), 7.10-$ $7.22(\mathrm{~m}, 8 \mathrm{H}), 7.36(\mathrm{dd}, J=7.8 \mathrm{~Hz}, 1.2 \mathrm{~Hz}, 1 \mathrm{H}), 7.68(\mathrm{~d}, J=7.2 \mathrm{~Hz}$, 2H), 7.76 (dd, $J=7.5 \mathrm{~Hz}, 1.2 \mathrm{~Hz}, 1 \mathrm{H}) .{ }^{13} \mathrm{C}-\mathrm{NMR}\left(\mathrm{CDCl}_{3}, 125\right.$
$\mathrm{MHz}) \delta$ (ppm): 16.09, 23.24, 38.35, 55.81, 56.06, 125.00, 125.50, 126.85, 126.98, 127.28, 128.84, 129.33, 131.96, 135.08, 137.61, 137.69, 140.90. HRMS: calculated for $\mathrm{C}_{26} \mathrm{H}_{32} \mathrm{NS}_{3} 454.1652[\mathrm{M}+$ $\mathrm{H}]^{+}$; found 454.1701. Elemental analysis: calcd C 68.83, H 6.89, N 3.09, S 21.20; found C 68.77, H 6.96, N 2.94, S 21.36.

$\boldsymbol{N}, \boldsymbol{N}$-Bis(2-(isopropylthio)benzyl)-1-(2-(methylthio)phenyl)methanamine (6c). Compound $4 \mathbf{b}(2240 \mathrm{mg}, 9.13 \mathrm{mmol})$, compound $5 \mathrm{a}$ (700 mg, $4.57 \mathrm{mmol}$ ) and $\mathrm{K}_{2} \mathrm{CO}_{3}(2.83 \mathrm{~g}, 20.5$ $\mathrm{mmol})$ in acetonitrile $(330 \mathrm{~mL})$ resulted in $6 \mathbf{c}$ as lightly yellow oily liquid (1500 mg, 68.3\%). Eluent for chromatography: hexane-chloroform $75: 25 \rightarrow 20: 80 \rightarrow 0: 100 .{ }^{1} \mathrm{H}-\mathrm{NMR}$ $\left(\mathrm{CDCl}_{3}, 500 \mathrm{MHz}\right) \delta(\mathrm{ppm}): 1.24(\mathrm{~d}, J=6.9 \mathrm{~Hz}, 12 \mathrm{H}), 2.40(\mathrm{~s}, 3 \mathrm{H})$, 3.28 (sep, $J=6.9 \mathrm{~Hz}, 2 \mathrm{H}), 3.72(\mathrm{~s}, 2 \mathrm{H}), 3.83(\mathrm{~s}, 4 \mathrm{H}), 7.12-7.21(\mathrm{~m}$, $7 \mathrm{H}), 7.36$ (dd, $J=7.7 \mathrm{~Hz}, 1.6 \mathrm{~Hz} 2 \mathrm{H}), 7.67$ (d, $J=7.2 \mathrm{~Hz}, 1 \mathrm{H})$, 7.76 (dd, $J=7.7 \mathrm{~Hz}, 1.2 \mathrm{~Hz}, 2 \mathrm{H}) .{ }^{13} \mathrm{C}-\mathrm{NMR}\left(\mathrm{CDCl}_{3}, 125 \mathrm{MHz}\right) \delta$ (ppm): 16.05, 23.23, 38.32, 55.81, 56.05, 124.95, 125.44, 126.83, 126.95, 127.25, 128.84, 129.35, 131.96, 135.10, 137.67, 137.72, 141.00. HRMS: calculated for $\mathrm{C}_{28} \mathrm{H}_{35} \mathrm{NS}_{3}$ 482.1965 [M $\left.+\mathrm{H}\right]^{+}$; found 482.2012. Elemental analysis: calcd $\mathrm{C} 69.80, \mathrm{H} 7.32, \mathrm{~N}$ 2.91, S 19.97; found C 69.71, H 7.47, N 2.79, S 20.41.

Tris(2-(isopropylthio)benzyl)amine (6d). Compound $4 \mathrm{~b}$ (1180 mg, $5.43 \mathrm{mmol}$ ), compound $5 \mathbf{b}$ (504 mg, $2.78 \mathrm{mmol}$ ) and $\mathrm{K}_{2} \mathrm{CO}_{3}(2.00 \mathrm{~g}, 14.5 \mathrm{mmol})$ in acetonitrile $(250 \mathrm{~mL})$ yielded $\mathbf{6 d}$ as golden brown oily liquid (773 mg, 61.2\%). Eluent for chromatography: hexane-chloroform $80: 20 \rightarrow 20: 80 \rightarrow 0: 100 .{ }^{1} \mathrm{H}-$ NMR $\left(\mathrm{CDCl}_{3}, 500 \mathrm{MHz}\right) \delta(\mathrm{ppm}): 1.24(\mathrm{~d}, J=6.6 \mathrm{~Hz}, 18 \mathrm{H}), 3.27$ (sep, $J=6.6 \mathrm{~Hz}, 3 \mathrm{H}), 3.81$ (s, 6H), 7.12-7.15 (m, 3H), 7.19-7.21 $(\mathrm{m}, 3 \mathrm{H}), 7.36(\mathrm{dd}, J=7.6 \mathrm{~Hz}, 1.2 \mathrm{~Hz}, 1 \mathrm{H}), 7.75(\mathrm{dd}, J=7.5 \mathrm{~Hz}, 1.2$ $\mathrm{Hz}, 1 \mathrm{H}) .{ }^{13} \mathrm{C}-\mathrm{NMR}\left(\mathrm{CDCl}_{3}, 125 \mathrm{MHz}\right) \delta$ (ppm): 23.23, 38.30, 56.07, 126.82, 126.93, 129.38, 131.98, 135.13, 141.13. HRMS: calculated for $\mathrm{C}_{30} \mathrm{H}_{39} \mathrm{NS}_{3} 510.2278[\mathrm{M}+\mathrm{H}]^{+}$; found 510.2327 . Elemental analysis: calcd C 70.67, H 7.71, N 2.75, S 18.87; found C 70.40, H 8.03, N 2.56, S 19.07.

$\mathrm{N}$-(2-(tert-Butylthio)benzyl)- $\mathrm{N}$-(2-(methylthio)benzyl)-1-(2(methylthio)phenyl)methanamine (6e). Compound $4 a(451 \mathrm{mg}$, $2.08 \mathrm{mmol}$ ), compound 5c (206 $\mathrm{mg}, 1.06 \mathrm{mmol}$ ) and $\mathrm{K}_{2} \mathrm{CO}_{3}$ $(800 \mathrm{mg}, 5.79 \mathrm{mmol})$ in acetonitrile $(100 \mathrm{~mL})$ gave $6 \mathrm{e}$ as white solid (423 mg, 87.0\%). Eluent for chromatography: hexanechloroform $50: 50 \rightarrow 10: 90 .{ }^{1} \mathrm{H}-\mathrm{NMR}\left(\mathrm{CDCl}_{3}, 500 \mathrm{MHz}\right) \delta$ (ppm): 1.23 (s, 9H), $2.40(\mathrm{~s}, 6 \mathrm{H}), 3.71(\mathrm{~s}, 4 \mathrm{H}), 3.99(\mathrm{~s}, 2 \mathrm{H}), 7.12-$ $7.17(\mathrm{~m}, 7 \mathrm{H}), 7.31-7.35(\mathrm{~m}, 1 \mathrm{H}), 7.49$ (dd, $J=7.8 \mathrm{~Hz}, 1.4 \mathrm{~Hz}, 1 \mathrm{H})$, 7.67 (d, $7.2 \mathrm{~Hz}, 2 \mathrm{H}), 7.85$ (dd, $J=7.8 \mathrm{~Hz}, 1.1 \mathrm{~Hz}, 1 \mathrm{H}) .{ }^{13} \mathrm{C}-\mathrm{NMR}$ $\left(\mathrm{CDCl}_{3}, 125 \mathrm{MHz}\right) \delta$ (ppm): 16.11, 31.19, 47.32, 55.87, 56.82, 124.98, 125.53, 126.45, 127.27, 128.90, 129.11, 129.64, 132.32, 137.72, 137.74, 138.86, 144.89. HRMS: calculated for $\mathrm{C}_{27} \mathrm{H}_{33} \mathrm{NS}_{3}$ 468.1809 $[\mathrm{M}+\mathrm{H}]^{+}$; found 468.1855. Elemental analysis: calcd $\mathrm{C}$ 69.33, H 7.11, N 2.99, S 20.57; found C 68.65, H 7.26, N 2.89, S 20.59 .

$N, N$-Bis(2-(tert-butylthio)benzyl)-1-(2-(methylthio)phenyl)methanamine (6f). Compound 4c (1060 mg, $4.09 \mathrm{mmol})$, compound $5 \mathrm{a}$ (415 mg, $2.71 \mathrm{mmol})$ and $\mathrm{K}_{2} \mathrm{CO}_{3}(1.21 \mathrm{~g}, 8.76$ $\mathrm{mmol})$ in acetonitrile $(150 \mathrm{~mL})$ yielded $\mathbf{6 f}$ as golden brown oily liquid (542 mg, 51.9\%). Eluent for chromatography: hexanechloroform $50: 50 \rightarrow 0: 100 .{ }^{1} \mathrm{H}-\mathrm{NMR}\left(\mathrm{CDCl}_{3}, 500 \mathrm{MHz}\right) \delta$ (ppm): 1.22 (s, 18H), 2.40 (s, 3H), 3.68 (s, 2H), 3.95 (s, 4H), 7.11$7.16(\mathrm{~m}, 5 \mathrm{H}), 7.32-7.35(\mathrm{~m}, 2 \mathrm{H}), 7.49(\mathrm{~d}, J=7.8 \mathrm{~Hz}, 2 \mathrm{H}), 7.64(\mathrm{~d}, J$ $=7.5 \mathrm{~Hz}, 1 \mathrm{H}), 7.84(\mathrm{~d}, J=7.7 \mathrm{~Hz}, 2 \mathrm{H}) \cdot{ }^{13} \mathrm{C}-\mathrm{NMR}\left(\mathrm{CDCl}_{3}, 125\right.$ 
MHz) $\delta$ (ppm): 16.12, 31.21, 47.31, 55.92, 56.84, 124.96, 125.55, 126.43, 127.26, 128.92, 129.12, 129.66, 132.37, 137.86, 137.92, 138.89, 145.16. HRMS: calculated for $\mathrm{C}_{30} \mathrm{H}_{39} \mathrm{NS}_{3} 510.2278[\mathrm{M}+$ $\mathrm{H}]^{+}$; found 510.233. Elemental analysis: calcd C 70.67, H 7.71, N 2.75, S 18.87; found C 70.09, H 8.01, N 2.65, S 19.12.

Tris(2-(tert-butylthio)benzyl)amine (6g). Compound $4 \mathrm{c}$ (541 mg, $1.83 \mathrm{mmol})$, compound $5 \mathrm{c}(261 \mathrm{mg}, 1.33 \mathrm{mmol}$ ) and $\mathrm{K}_{2} \mathrm{CO}_{3}(810 \mathrm{mg}, 5.86 \mathrm{mmol})$ in acetonitrile $(100 \mathrm{~mL})$ resulted in $6 \mathrm{~g}$ as a white solid (386 mg, 76.5\%). Eluent for chromatography: hexane-chloroform $50: 50 \rightarrow 10: 90 .{ }^{1} \mathrm{H}-\mathrm{NMR} \quad\left(\mathrm{CDCl}_{3}\right.$, $500 \mathrm{MHz}) \delta(\mathrm{ppm}): 4.0(\mathrm{~s}, 27 \mathrm{H}), 3.92(\mathrm{~s}, 6 \mathrm{H}), 7.13-7.16(\mathrm{~m}, 3 \mathrm{H})$, $7.33-7.35(\mathrm{~s}, 3 \mathrm{H}), 7.49(\mathrm{dd}, J=7.7 \mathrm{~Hz}, 1.2 \mathrm{~Hz}, 3 \mathrm{H}), 7.82(\mathrm{dd}, J=$ $7.8 \mathrm{~Hz}, 1.2 \mathrm{~Hz}, 3 \mathrm{H}) .{ }^{13} \mathrm{C}-\mathrm{NMR}\left(\mathrm{CDCl}_{3}, 125 \mathrm{MHz}\right) \delta(\mathrm{ppm}): 31.20$, 42.27, 56.71, 126.38, 129.10, 129.59, 132.41, 138.89, 145.37. HRMS: calculated for $\mathrm{C}_{33} \mathrm{H}_{45} \mathrm{NS}_{3} 552.2748[\mathrm{M}+\mathrm{H}]^{+}$; found = 552.2795. Elemental analysis: calcd C 71.81, H 8.22, N 2.54, S 17.43; found C 71.49, H 8.49, N 2.48, S 17.70.

\section{Extraction experiments}

In a $50 \mathrm{~mL}$ centrifuge tube, an aliquot of chloroform containing $1 \times 10^{-5}$ to $2 \times 10^{-3} \mathrm{M}$ of each ligand $(\mathbf{6 a}-\mathbf{g})$ and an equal volume of aqueous buffer solution containing $10 \mathrm{mg} \mathrm{L}^{-1}$ of $\mathrm{Ag}^{+}$ as $\mathrm{AgNO}_{3}$, were mixed. Buffer solutions were prepared from $10 \mathrm{mM}$ acetic acid and the $\mathrm{pH}$ values were adjusted by varying the ratio of potassium nitrate and potassium hydroxide, with the total potassium ion concentration adjusted to $100 \mathrm{mM}$. The centrifuge tubes were then shaken at $25{ }^{\circ} \mathrm{C}$ over $3 \mathrm{~h}$. After the two phases were separated by centrifugation, the $\mathrm{pH}$ values ( $\mathrm{pH}$ electrode) and the metal concentrations (ICP-AES) in the aqueous phase were measured. Moreover, the organic phase was shaken at $25{ }^{\circ} \mathrm{C}$ over $3 \mathrm{~h}$ with $1 \mathrm{M} \mathrm{HNO}_{3}$ as back extraction solvent. After separation in the same way, $\mathrm{Ag}^{+}$concentrations in the aqueous phase (back extraction phase) were measured.

The extraction efficiencies, back extraction efficiencies, and total extraction efficiencies were determined based on the $\mathrm{Ag}^{+}$ concentrations in each set of aqueous phases according to the following equations,

$$
\begin{gathered}
\text { Extraction efficiency }(\%)=\left(C_{\mathrm{w}}-C_{\mathrm{e}}\right) / C_{\mathrm{w}} \times 100 \\
\text { Back extraction efficiency }(\%)=C_{\mathrm{e}}^{\prime} /\left(C_{\mathrm{w}}-C_{\mathrm{e}}\right) \times 100 \\
\text { Total extraction efficiency }(\%)=C_{\mathrm{e}}^{\prime} / C_{\mathrm{w}} \times 100
\end{gathered}
$$

where $C_{\mathrm{w}}, C_{\mathrm{e}}$, and $C_{\mathrm{e}}^{\prime}$ correspond to the $\mathrm{Ag}^{+}$ion concentrations in the aqueous phase before extraction, after extraction, and in the back extraction aqueous phase, respectively.

Extraction efficiencies for other ions were evaluated according to the same procedure as described for $\mathrm{Ag}^{+}$.

\section{Results and discussion}

\section{Molecular design and synthesis}

As sterically demanding groups in the sidearms, the $\mathrm{Ag}^{+}$ extracting ligands include combinations of methyl and isopropyl, or methyl and tert-butyl substituents. The target compounds were obtained by the $\mathrm{S}_{\mathrm{N}} 2$ reactions of 2 equivalents
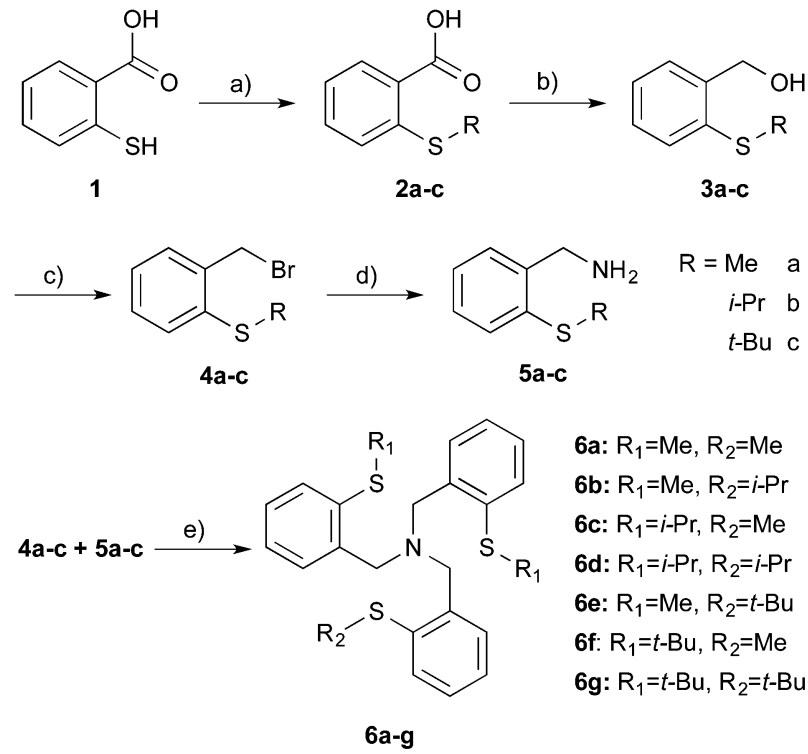

Scheme 1 (a) $\mathrm{CH}_{3}$ l, i-PrBr or $t-\mathrm{BuOH}$ (b) $\mathrm{BH}_{3} \cdot \mathrm{THF}, \mathrm{THF}$ (c) $\mathrm{PBr}_{3}, \mathrm{Et}_{2} \mathrm{O}$ (d) $\mathrm{NH}_{3}$ aq., $\mathrm{EtOH}$ (e) $\mathrm{K}_{2} \mathrm{CO}_{3}, \mathrm{CH}_{3} \mathrm{CN}$.

of bromo derivatives and 1 equivalent of amine derivatives (Scheme 1). This synthesis method enables the access to ligands having combinations of various substituents. Though there are some literature reports about tripodal ligands with three identical coordinating arms for extraction, to the best of our knowledge, the effect of combinations of sidearms in tripodal ligands has not yet been evaluated in terms of extraction and back-extraction efficiencies. In this work, the effect of the combination of sterically demanding groups on the extraction and back-extraction efficiency was examined. All ligands have multiple sulfur atoms as "soft" bases and efficiently extract $\mathrm{Ag}^{+}$ ions as "soft" acid according to the HSAB concept.

\section{Determination of the extraction constant and confirmation of 1:1 complex stoichiometry}

Extraction behavior of $\mathrm{Ag}^{+}$with ligands in chloroform: the distribution ratio $(D)$ of the silver ion is defined as

$$
D=\frac{C_{\mathrm{Ag}, \text { org }}}{C_{\mathrm{Ag}, \text { aq }}}
$$

where $C_{\mathrm{Ag} \text {, org }}$ and $C_{\mathrm{Ag} \text {, aq. }}$ are the total concentrations of $\mathrm{Ag}^{+}$ions in the organic and aqueous phases, respectively.

The extraction equilibrium can be formulated as

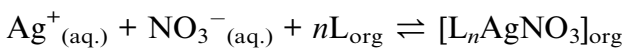

The extraction constant, $K_{\mathrm{ex}}$, of $\mathrm{Ag}^{+}$with the ligand is expressed as

$$
K_{\mathrm{ex}}=\frac{\left[\mathrm{L}_{n} \mathrm{AgNO}_{3}\right]_{\mathrm{org}}}{\left[\mathrm{Ag}^{+}\right]_{\text {aq. }}\left[\mathrm{NO}_{3}{ }^{-}\right]_{\text {aq. }}[\mathrm{L}]_{\mathrm{org}}{ }^{n}}
$$

As the total concentration of $\mathrm{Ag}^{+}$ions in the organic phase corresponds to $\left[\mathrm{L}_{n} \mathrm{AgNO}_{3}\right]$, the distribution ratio of $\mathrm{Ag}^{+}$can be rewritten as 


$$
D=\frac{\left[\mathrm{L}_{n} \mathrm{AgNO}_{3}\right]_{\mathrm{org}}}{\left[\mathrm{Ag}^{+}\right]_{\mathrm{aq}}}
$$

Substitution of eqn (3) into (4) results in the following

$$
D /\left[\mathrm{NO}_{3}{ }^{-}\right]_{\mathrm{aq} .}=K_{\mathrm{ex}}[\mathrm{L}]_{\mathrm{org}}{ }^{n}
$$

Taking the logarithm of eqn (5) yields

$$
\log D /\left[\mathrm{NO}_{3}{ }^{-}\right]_{\text {aq. }}=\log K_{\mathrm{ex}}+n \log [\mathrm{L}]_{\text {org }}
$$

To confirm the complex stoichiometry with $\mathrm{Ag}^{+}$, as well as to estimate the extraction constant $\left(K_{\text {ex }}\right)$ of each ligand for $\mathrm{Ag}^{+}$, the distribution ratio $D$ was determined as a function of the ligand concentration. Plots of $\log \left(D /\left[\mathrm{NO}_{3}{ }^{-}\right]_{\mathrm{aq}}\right)$ versus the concentration of each ligand with different steric hindrance, $\log [\mathrm{L}]_{\text {org }}$, at fixed pH of 4.0 are shown in Fig. 1. In all cases, straight lines with a slope of one are observed, confirming a $1: 1$ complex formation according to eqn (6). A schematic representation of a complex is shown in Scheme 2. This indicates that the stoichiometry of complexes formed with $\mathrm{Ag}^{+}$is identical for all ligands, independent of the sidearms having different steric hindrance characteristics. ESI-MS mass spectra of mixtures of each ligand and $\mathrm{AgClO}_{4}$ also revealed the formation of a $1: 1$ complex through the metal coordination interaction, with two peaks (derived from $\mathrm{Ag}^{+}$isotopes) assigned to the species $[\mathbf{6 a}-\mathbf{g}+\mathrm{Ag}]^{+}$, respectively (shown in the ESI $\dagger$ ). In addition, ${ }^{1} \mathrm{H}$ and ${ }^{13} \mathrm{C}-\mathrm{NMR}$

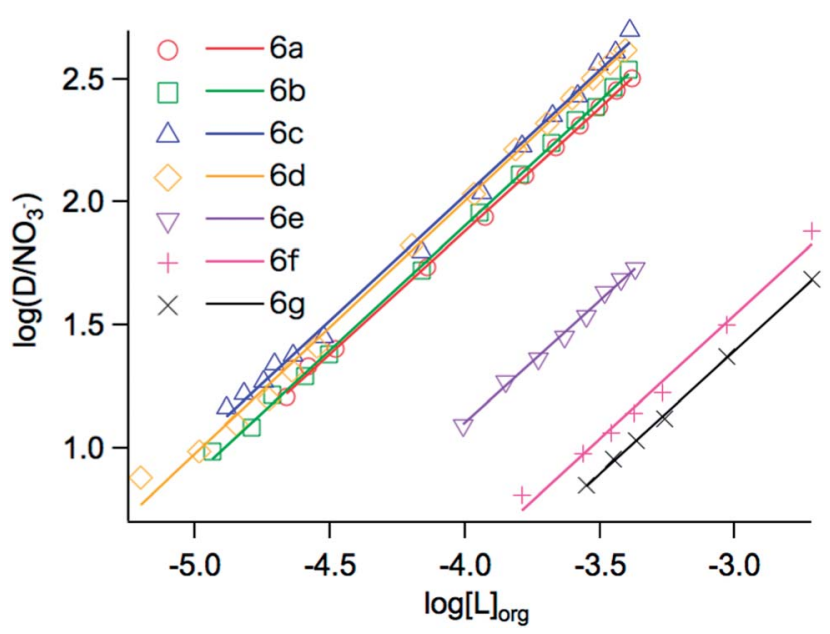

Fig. 1 Plots of $\log \left(D / \mathrm{NO}_{3}{ }^{-}\right)$versus log $[\mathrm{L}]_{\text {org }}$ for the extraction of $10 \mathrm{mg}$ $\mathrm{L}^{-1} \mathrm{Ag}^{+}$as $\mathrm{AgNO}_{3}$ with 6a-g into chloroform; aqueous phase: $\mathrm{pH}$ 4.0.<smiles>[R]S[C@]12Sc3ccccc3C(c3ccccc31)N1Cc3ccccc3S[Z17]1([Y])S2</smiles>

Scheme 2 General schematic representation of the structure of complexes formed between the tripodal ligands and $\mathrm{Ag}^{+}$.
Table 1 Extraction constants $\left(K_{\text {ex }}\right)$ of each ligand for $\mathrm{Ag}^{+}$, and slope and correlation coefficient $\left(R^{2}\right)$ of linear regression lines (data extracted from Fig. 1)

\begin{tabular}{llllllll}
\hline & $\mathbf{6 a}$ & $\mathbf{6 b}$ & $\mathbf{6 c}$ & $\mathbf{6 d}$ & $\mathbf{6 e}$ & $\mathbf{6 f}$ & $\mathbf{6 g}$ \\
\hline Slope & 1.00 & 1.02 & 1.01 & 1.03 & 1.00 & 1.01 & 1.00 \\
$R^{2}$ & 0.999 & 0.999 & 0.996 & 0.996 & 0.996 & 0.987 & 0.999 \\
$\log K_{\text {ex }}$ & 5.89 & 5.97 & 6.04 & 6.12 & 5.10 & 4.57 & 4.40 \\
\hline
\end{tabular}

spectra of $6 \mathbf{a}$ in the presence of $\mathrm{AgNO}_{3}$ showed changes of the chemical shifts compared to the spectra recorded in the absence of $\mathrm{AgNO}_{3}$ (shown in the ESI $\dagger$ ). These results further demonstrate the interaction of the ligand with $\mathrm{Ag}^{+}$. Table 1 lists the extraction constants $\left(K_{\text {ex }}\right)$ of each ligand for $\mathrm{Ag}^{+}$, estimated according to eqn (6) from the intercept of the linear regression lines shown in Fig. 1. With an increasing number of $t$-Bu substituents in compounds $6 \mathbf{6 a}, \mathbf{6 e - g}, K_{\mathrm{ex}}$ decreased from 5.89 to $5.10,4.57$ and 4.40, respectively. This might be the result of increasing binding distances between $\mathrm{Ag}^{+}$and the donor $\mathrm{S}$ atoms, as well as the hindrance of binding between the counter anion and $\mathrm{Ag}^{+}$, caused by the bulky $t$-Bu substituent directly connected to the $\mathrm{S}$ atoms. On the other hand, with increasing number of i-Pr substituents in compounds $\mathbf{6 b}-\mathbf{d}, K_{\mathrm{ex}}$ slightly increased to 5.97, 6.04 and 6.12, respectively. The inductive effect of alkyl groups increases in the order of methyl, i-Pr, and $t$-Bu. It has been reported that the inductive effect sometimes outweighs the steric effect on the complex formation constant of a ligand with a metal ion. ${ }^{30}$ In analogy to that work, it is assumed that the steric hindrance effects of the i-Pr substituents in compounds 6a-d are outweighed by the inductive effects.

\section{Crystal structure studies}

$\mathrm{X}$-ray single crystal structural analysis was performed to determine the molecular structures of complexes formed between
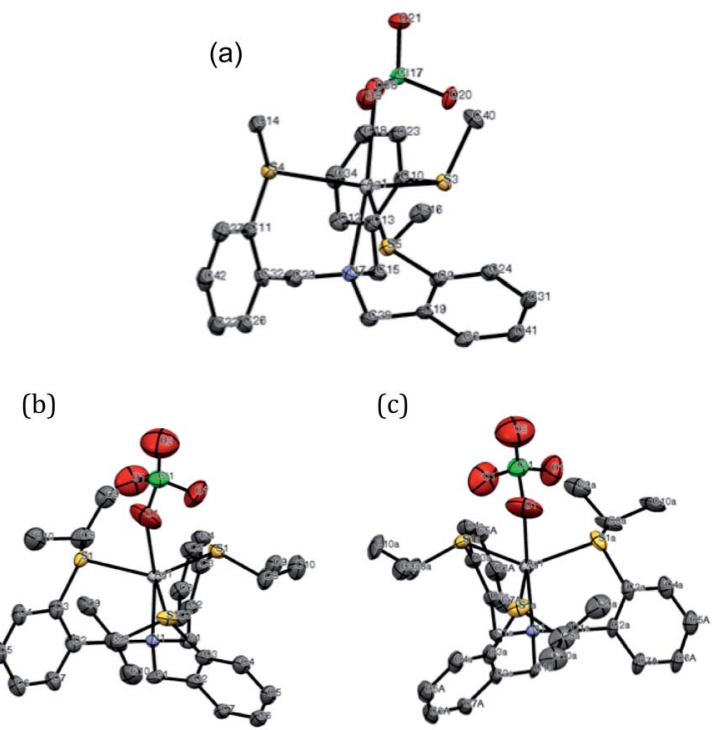

Fig. 2 X-ray single crystal structures of (a) $6 a$ and (b) $6 \mathrm{dA}$ (c) $6 \mathrm{~dB}$ complexing $\mathrm{Ag}^{+}$. 
the ligands and $\mathrm{Ag}^{+}$. Since single crystals were more readily obtained as perchlorate salts than nitrate salts, $\mathrm{AgClO}_{4}$ was applied in crystallization experiments. Nevertheless, crystals sufficiently large for X-ray analysis were only achieved with ligands $\mathbf{6 a}$ and $\mathbf{6 d}$. X-ray crystal structures of the two complexes $\mathrm{Ag}(6 \mathbf{6}) \mathrm{ClO}_{4}$ and $\mathrm{Ag}(\mathbf{6 d}) \mathrm{ClO}_{4}$ are shown in Fig. 2, together with selected structural parameters listed in Table 2 . With respect to $\mathrm{Ag}(\mathbf{6 d}) \mathrm{ClO}_{4}$, two crystallographically independent complexes (6dA and 6dB) were observed (Fig. 2b and c). The binding characteristics of ligands $6 \mathbf{a}$ and $\mathbf{6 d A}$ and $\mathbf{6 d B}$ with $\mathrm{Ag}^{+}$are basically identical, with both compounds forming the same 5 -fold coordinated complexes. $\mathrm{Ag}^{+}$is coordinated by one $\mathrm{N}$ atom $(\mathrm{Ag}-\mathrm{N}=2.606 \AA$ in $6 \mathrm{a}$ and $2.456 \AA$ in $6 \mathrm{~d})$, three $\mathrm{S}$ atoms $(\mathrm{Ag}-\mathrm{S}=$ $2.558 \pm 0.006 \AA$ in $6 \mathbf{a}$ and $2.54 \AA$ in $\mathbf{6 d A}$ and $2.49 \AA$ in $6 \mathbf{d B}$ ) and one $\mathrm{O}$ atom from $\mathrm{ClO}_{4}{ }^{-}(\mathrm{Ag}-\mathrm{O}=2.576 \AA$ in $6 \mathbf{a}$ and $3.29 \AA$ in $6 \mathbf{d A}$ and $\mathbf{6 d B}$ ). The distance between silver and each sulfur atom is slightly shorter than the mean $(2.675 \pm 0.015 \AA)$ of 51 such bonds taken from the X-ray literature. ${ }^{31}$ Regardless of the substituent (Me or i-Pr), the $\mathbf{A g}^{+}-\mathrm{S}$ bond lengths of $\mathbf{6 a}$ and $\mathbf{6 d}$ are nearly the same. This result implies that the sterically more demanding i-Pr moiety does not influence the binding ability of sulfur to $\mathrm{Ag}^{+}$, and it is adequate for the extraction constants $\left(K_{\text {ex }}\right.$ values) of ligands $\mathbf{6 a - d}$ to slightly increase with increasing number of i-Pr groups according to the inductive effect. On the other hand, the distance between $\mathrm{Ag}^{+}$and $\mathrm{ClO}_{4}{ }^{-}$of $\mathrm{Ag}(\mathbf{6 a}) \mathrm{ClO}_{4}$ and $\mathrm{Ag}(\mathbf{6 d}) \mathrm{ClO}_{4}$ are clearly different. This indicates that the presence of a sterically hindering substituent influences the distance between $\mathrm{Ag}^{+}$and the counter anion.

Table 2 Selected bond lengths for $6 \mathrm{a}$ and $6 \mathrm{~d}$ complexing $\mathrm{Ag}^{+}$

\begin{tabular}{llllll}
\hline $\mathbf{6 a}$ & & $\mathbf{6 d A}$ & & $\mathbf{6 d B}$ & \\
\hline $\mathrm{Ag}(1)-\mathrm{S}(3)$ & $2.5665(8)$ & $\mathrm{Ag}(1)-\mathrm{S}(1)$ & $2.54(1)$ & $\mathrm{Ag}(1)-\mathrm{S}(1)$ & $2.49(1)$ \\
$\mathrm{Ag}(1)-\mathrm{S}(4)$ & $2.5593(8)$ & $\mathrm{Ag}(1)-\mathrm{S}(1)$ & $2.54(1)$ & $\mathrm{Ag}(1)-\mathrm{S}(1)$ & $2.487(9)$ \\
$\mathrm{Ag}(1)-\mathrm{S}(5)$ & $2.548(1)$ & $\mathrm{Ag}(1)-\mathrm{S}(1)$ & $2.542(7)$ & $\mathrm{Ag}(1)-\mathrm{S}(1)$ & $2.49(2)$ \\
$\mathrm{Ag}(1)-\mathrm{N}(7)$ & $2.606(2)$ & $\mathrm{Ag}(1)-\mathrm{N}(1)$ & $2.456(4)$ & $\mathrm{Ag}(1)-\mathrm{N}(1)$ & $2.456(4)$ \\
$\mathrm{Ag}(1)-\mathrm{O}(38)$ & $2.576(2)$ & $\mathrm{Ag}(1)-\mathrm{O}(1)$ & $3.29(1)$ & $\mathrm{Ag}(1)-\mathrm{O}(1)$ & $3.29(1)$
\end{tabular}

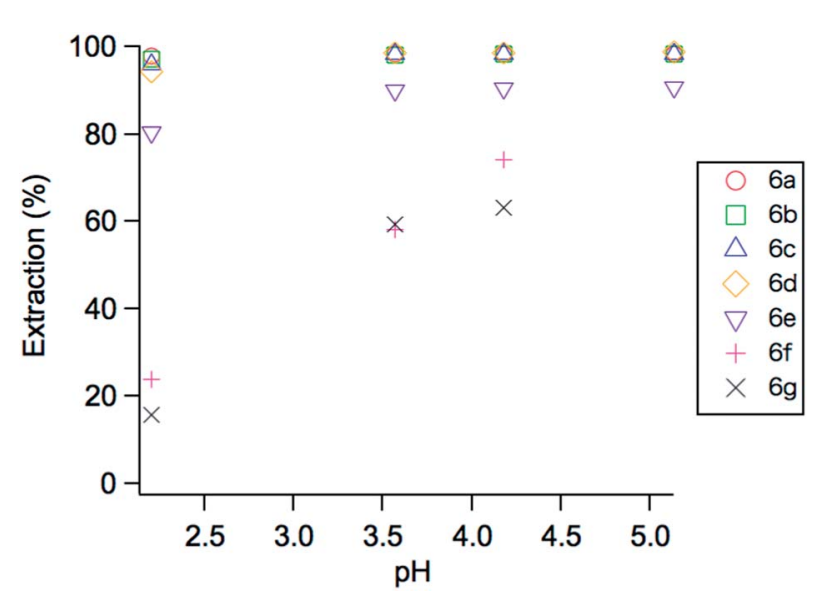

Fig. 3 Extraction of $\mathrm{Ag}^{+}$with various ligands as a function of the equilibrium $\mathrm{pH}$ of the aqueous phase; ligand concentration $1 \mathrm{mM}$.

\section{Extraction and back-extraction behavior}

The extraction efficiencies (\%) of $\mathrm{Ag}^{+}$with each ligand as a function of equilibrium $\mathrm{pH}$ in the aqueous phase are shown in Fig. 3. $\mathrm{Ag}^{+}$was efficiently extracted with ligands $\mathbf{6 a - d}$ (increasing number of sterically demanding i-Pr groups) independent of the $\mathrm{pH}$ of the aqueous phase. The extraction efficiencies of $\mathrm{Ag}^{+}$with $\mathbf{6 e}-\mathbf{g}$ (increasing number of $t$-Bu groups) decreased with decreasing $\mathrm{pH}$. This behavior was particularly pronounced for 6f and $\mathbf{6 g}$. The results in Fig. 4 show the extraction efficiencies (\%) of $6 \mathbf{a}$ for various other ions as a function of equilibrium $\mathrm{pH}$ in the aqueous phase. Independent of the $\mathrm{pH}$ of the aqueous phase, no significant extraction was observed for most ions, with the exception of $\mathrm{Hg}^{2+}$, which was extracted at an efficiency of about $8 \%$. According to the HSAB concept, this extraction can be attributed to the relatively strong affinity of the sulfur atoms, characterized as 'soft' bases, for the 'soft' acid $\mathrm{Hg}^{2+}$. However, in accordance with the only limited extraction efficiency for $\mathrm{Hg}^{2+}$, these results demonstrate that ligand 6a has a suitably high selectivity for extraction of $\mathrm{Ag}^{+}$. The extraction efficiencies (\%) of $\mathrm{Ag}^{+}$with each ligand under identical $\mathrm{pH}$ condition of the aqueous phase (pH 4.0) are shown in Fig. 5a. The values of the extraction constants (Table 1) are directly reflected in the extraction efficiencies. In the case of ligands $\mathbf{6 b}-\mathbf{d}$ (with i-Pr groups), the extraction efficiency was constantly high. In the case of ligands $\mathbf{6 e -} \mathbf{g}$ (with $t$-Bu groups), the extraction efficiency decreased with increasing number of $t$-Bu groups. The backextraction efficiencies (\%) of $\mathrm{Ag}^{+}$with each ligand for a $1 \mathrm{M}$ $\mathrm{HNO}_{3}$ aqueous phase are shown in Fig. 5b. In the case of compound 6a, the back-extraction efficiency was only about $35 \%$ and not sufficient. This might be attributed to the strong interaction of $\mathrm{S}$ and $\mathrm{Ag}^{+} \cdot{ }^{32}$ In the case of ligands $\mathbf{6 b}-\mathbf{d}$, the backextraction efficiency increased with increasing number of i-Pr groups.

Extraction and back-extraction efficiencies have been investigated using nitrate salts, due to their solubility in water over a wide concentration range, while X-ray analysis was done on complexes with perchlorate as the counter anion, because more ready crystallization. For comparison purposes, some extraction and back-extraction experiments were performed with $\mathrm{AgClO}_{4}$. The extraction efficiency and back-extraction efficiency (\%) of $\mathrm{Ag}^{+}$as $\mathrm{AgNO}_{3}$ or $\mathrm{AgClO}_{4}$ with $\mathbf{6 d}$ under identical $\mathrm{pH}$ condition of

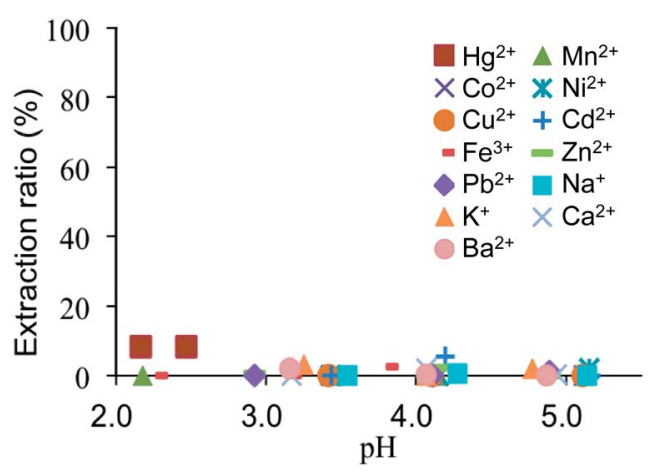

Fig. 4 Extraction of various ions with $6 \mathrm{a}$ as a function of the equilibrium $\mathrm{pH}$ of the aqueous phase; ligand concentration $1 \mathrm{mM}$. 
(a)

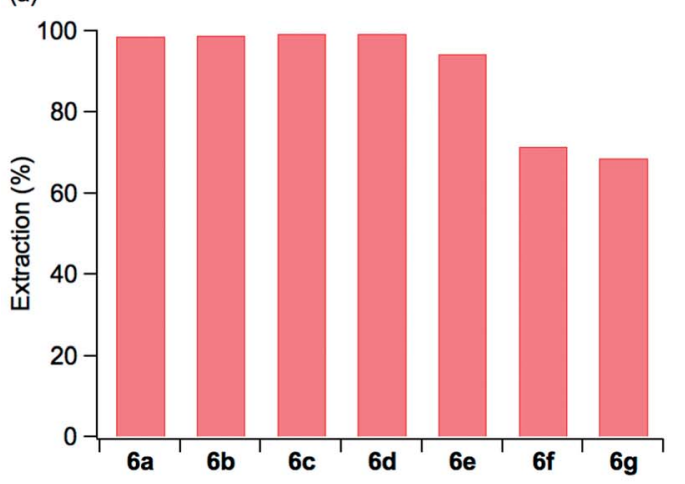

(b)

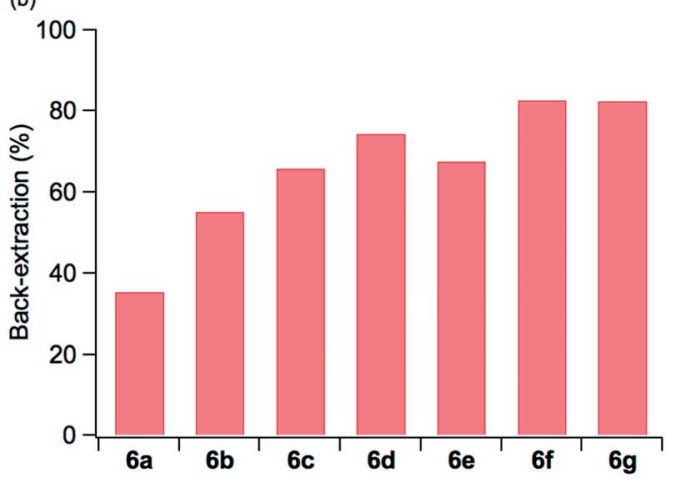

(c)

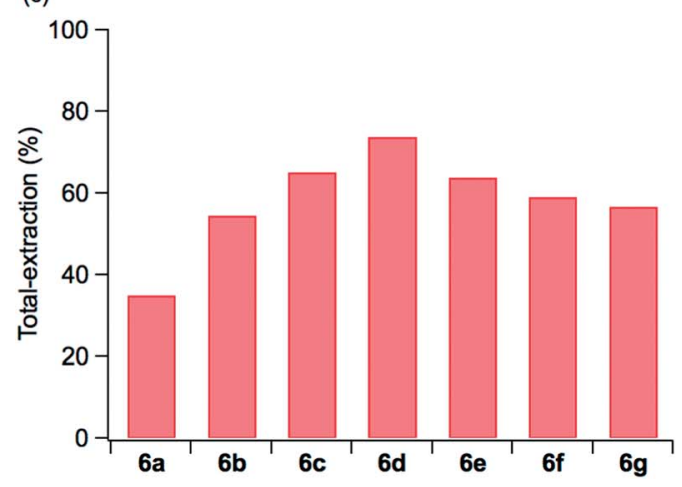

Fig. 5 (a) Extraction, (b) back-extraction, and (c) total-extraction efficiencies of $\mathrm{Ag}^{+}$with various ligands; aqueous phase: $\mathrm{pH}$ 4.0; organic phase: ligand concentration $1 \mathrm{mM}$; back-extraction solvent: 1 $\mathrm{M} \mathrm{HNO}_{3}$ aqueous solution.

Table 3 Counter anion dependent extraction and back-extraction efficiencies of $6 \mathrm{a}$ and $6 \mathrm{~d}$ for $\mathrm{Ag}^{+}$

\begin{tabular}{lllll}
\hline Ligand & Anion & Extraction & Back-extraction & Total-extraction \\
\hline \multirow{2}{*}{ 6a } & $\mathrm{NO}_{3}$ & $98.8 \%$ & $35.4 \%$ & $35.0 \%$ \\
& $\mathrm{ClO}_{4}$ & $99.0 \%$ & $35.7 \%$ & $35.3 \%$ \\
6d & $\mathrm{NO}_{3}$ & $99.4 \%$ & $74.5 \%$ & $74.0 \%$ \\
& $\mathrm{ClO}_{4}$ & $98.4 \%$ & $72.1 \%$ & $71.0 \%$
\end{tabular}

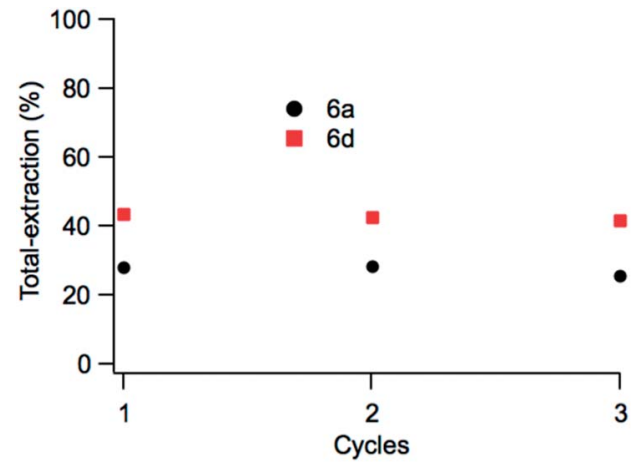

Fig. 6 Total extraction efficiencies for the extraction of $200 \mathrm{mg} \mathrm{L}^{-1}$ $\mathrm{Ag}^{+}$as $\mathrm{AgNO}_{3}$ with 6a or 6d; aqueous phase: $\mathrm{pH}$ 4.0; organic phase: ligand concentration $1 \mathrm{mM}$; back-extraction solvent: $1 \mathrm{M} \mathrm{HNO}_{3}$.

the aqueous phase ( $\mathrm{pH} 4.0)$ are shown in Table 3. No significant differences in the extraction and back-extraction efficiencies of $\mathrm{AgNO}_{3}$ and $\mathrm{AgClO}_{4}$ were observed.

From X-ray single crystal structural analysis of complexes formed with $\mathbf{6 a}$ and $\mathbf{6 d}$, the distance between the $\mathrm{Ag}^{+}$ion and the counter anion was larger in the complex of $\mathbf{6 d}$ than of $\mathbf{6 a}$. Therefore, the difference of the distance between $\mathrm{Ag}^{+}$and the counter anion might affect the back-extraction efficiencies. Similar to ligands $\mathbf{6 b}-\mathbf{d}$ with increasing number of i-Pr groups, the back-extraction efficiency of compounds $\mathbf{6 e -} \mathbf{g}$ increased with increasing number of $t$-Bu groups. These results again reflect the decreasing values of the extraction constants (Table 1), with increasing number of $t$-Bu groups.

The total extraction efficiencies (\%) combining the extraction and back-extraction processes of $\mathrm{Ag}^{+}$with each ligand are shown in Fig. 5c. With increasing number of i-Pr substituents (6a-d), the total extraction efficiencies increased up to $74 \%$. The total extraction efficiencies decreased down to $57 \%$ with increasing number of $t$-Bu substituents. The total extraction efficiency of $\mathbf{6 d}$ was highest among the synthesized ligands (6ag), because of the relatively high efficiency of both extraction and back-extraction. These results indicate that the steric hindrance of the alkyl-substituted thioether arms of the tripodal ligands affects the total extraction efficiency.

The reusability of ligands ( $6 \mathbf{a}$ and $\mathbf{6 d}$ ) was evaluated as shown in Fig. 6 . The total extraction efficiency of both ligands is hardly altered after three repeated cycles. These results indicate that these ligands are applicable to the repeated extraction of $\mathrm{Ag}^{+}$.

\section{Conclusions}

A series of tripodal ligands for $\mathrm{Ag}^{+}$with thiophenylether sidearms carrying different sterically demanding groups have been successfully synthesized. The extraction and back-extraction efficiencies of these ligands depend on the number and size of sterically hindering groups. The extraction efficiencies decrease with increasing number of $t$-Bu groups. The back-extraction efficiencies increase with increasing number of i-Pr and $t$-Bu groups. The total extraction efficiency of ligand $\mathbf{6 d}$ having three 
i-Pr groups was highest in the new series of tripodal ligands (6ag). These results indicate that the extraction efficiencies and the back-extraction efficiencies are controlled by the combination of sterically hindering groups present in the ligand binding arms. It is expected that these findings can be applied for the design of new metal extractants.

\section{Notes and references}

1 Z. Dai and J. W. Canary, New J. Chem., 2007, 31, 1708-1718. 2 M. Schatz, M. Becker, F. Thaler, F. Hampel, S. Schindler, R. R. Jacobson, Z. Tyeklar, N. N. Murthy, P. Ghosh, Q. Chen, J. Zubieta and K. D. Karlin, Inorg. Chem., 2001, 40, 2312-2322.

3 N. Wei, N. N. Murthy, Q. Chen, J. Zubieta and K. D. Karlin, Inorg. Chem., 1994, 33, 1953-1965.

4 J. T. Hoffman and C. J. Carrano, Inorg. Chim. Acta, 2006, 359, 1248-1254.

5 H. W. Yim, L. M. Tran, E. D. Dobbin, D. Rabinovich, L. M. Liable-Sands, C. D. Incarvito, K.-C. Lam and A. L. Rheingold, Inorg. Chem., 1999, 38, 2211-2215.

6 R. Wietzke, M. Mazzanti, J.-M. Latour, J. Pécaut, P.-Y. Cordier and C. Madic, Inorg. Chem., 1998, 37, 6690-6697.

7 N. Hirayama, Y. Horita, S. Oshima, K. Kubono, H. Kokusen and T. Honjo, Talanta, 2001, 53, 857-862.

8 R. J. Warr, A. N. Westra, K. J. Bell, J. Chartres, R. Ellis, C. Tong, T. G. Simmance, A. Gadzhieva, A. J. Blake, P. A. Tasker and M. Schroder, Chem. - Eur. J., 2009, 15, 4836-4850.

9 K. Matloka, A. K. Sah, M. W. Peters, P. Srinivasan, A. V. Gelis, M. Regalbuto and M. J. Scott, Inorg. Chem., 2007, 46, 1054910563.

10 A. Pellissier, Y. Bretonniere, N. Chatterton, J. Pecaut, P. Delangle and M. Mazzanti, Inorg. Chem., 2007, 46, 3714-3725.

11 C. Kar, M. Deb Adhikari, A. Ramesh and G. Das, RSC Adv., 2012, 2, 9201-9206.

12 A. Sengupta, P. K. Mohapatra, M. Iqbal, W. Verboom, J. Huskens and S. V. Godbole, RSC Adv., 2012, 2, 7492-7500.

13 H. Okamura, A. Ikeda-Ohno, T. Saito, N. Aoyagi, H. Naganawa, N. Hirayama, S. Umetani, H. Imura and K. Shimojo, Anal. Chem., 2012, 84, 9332-9339.
14 B. Swain, J. Jeong, S.-k. Kim and J.-c. Lee, Hydrometallurgy, 2010, 104, 1-7.

15 R. Banda, H. S. Jeon and M. S. Lee, Hydrometallurgy, 2012, 121-124, 74-80.

16 A. H. Bond, M. L. Dietz and R. Chiarizia, Ind. Eng. Chem. Res., 2000, 39, 3442-3464.

17 K. Ohto, Solvent Extr. Res. Dev., Jpn., 2010, 17, 1-18.

18 M. Iwakuma, T. Ohshima and Y. Baba, Solvent Extr. Res. Dev., Jpn., 2008, 15, 21-35.

19 H. Narita, K. Morisaku and M. Tanaka, Chem. Commun., 2008, 5921-5923.

20 R. G. Pearson, J. Am. Chem. Soc., 1963, 85, 3533-3539.

21 I. Vujasinović, J. Veljković, K. Molcanov, B. Kojić-Prodić and K. Mlinarić-Majerski, J. Org. Chem., 2008, 73, 92219227.

22 R. Alberto, W. Nef, A. Smith, T. A. Kaden, M. Neuburger, M. Zehnder, A. Frey, U. Abram and P. A. Schubiger, Inorg. Chem., 1996, 35, 3420-3427.

23 T. Nabeshima, K. Nishijima, N. Tsukada, H. Furusawa, T. Hosoya and Y. Yano, J. Chem. Soc., Chem. Commun., 1992, 1092-1094.

24 P. A. Vigato, S. Tamburini and L. Bertolo, Coord. Chem. Rev., 2007, 251, 1311-1492.

25 A. T. Yordanov, B. R. Whittlesey and D. M. Roundhill, Inorg. Chem., 1998, 37, 3526-3531.

26 N. Singh and G. Hundal, J. Inclusion Phenom. Macrocyclic Chem., 2005, 52, 253-259.

27 L. G. A. van de Water, F. ten Hoonte, W. L. Driessen, J. Reedijk and D. C. Sherrington, Inorg. Chim. Acta, 2000, 303, 77-85.

28 G. M. Sheldrick, Acta Crystallogr., Sect. A: Found. Crystallogr., 2008, 64, 112-122.

29 H. V. Huynh, C. H. Yeo and Y. X. Chew, Organometallics, 2010, 29, 1479-1486.

30 K. V. Damu, H. Maumela, R. D. Hancock, J. C. A. Boeyens and S. M. Dobson, J. Chem. Soc., Dalton Trans., 1991, 2717-2721.

31 S. S. Lee, I. Yoon, K.-M. Park, J. H. Jung, L. F. Lindoy, A. Nezhadali and G. Rounaghi, J. Chem. Soc., Dalton Trans., 2002, 2180-2184.

32 H. W. Mbatia, D. P. Kennedy and S. C. Burdette, Photochem. Photobiol., 2012, 88, 844-850. 